\title{
Articles
}

\section{Some Keywords in Chinese Historical Thinking: An East Asian and World Perspective}

\author{
Chun-chieh HUANG* and Alan T. WOOD**
}

\section{Preface:}

The two authors of this article first became friends more than forty years ago in graduate school at the University of Washington. Both of us were inspired by Professor Hsiao Kung-ch'uan 蕭公權, one of the great scholars of Chinese political thought in the twentieth century. At that time, he had retired from teaching at the University but often visited the campus for colloquia and other events. Although Chun-chieh and Alan's subsequent careers developed in universities geographically distant from each other, the former at National Taiwan University and the latter at a new campus of the University of Washington, we have reconnected later in life and discovered that Professor Hsiao's insights into the Confucian tradition have continued to illuminate our scholarship throughout the years.

Chun-chieh has focused his attention on the impact of the Confucian thinker Mencius on Chinese political thought, as well as the impact of Confucianism on the East Asian region in general. Alan has complemented his scholarship on China with a focus on the world as a whole, trying to understand how the lessons of governance revealed by China and by the rise and fall of human civilizations might be applied to the world today. Given the confluence of our two careers and the challenges of governance faced by the increasingly interdependent world we live in, we have both found ourselves returning for inspiration to the well of Confucian humanistic wisdom that has nurtured Chinese intellectuals for more than two thousand years. This essay is a discussion of some of the key terms in Chinese historiography in the past, followed by some thoughts on how those terms, as well as the holistic worldview that emerged in the great intellectual synthesis of Confucius and

* Chun-chieh HUANG 黄俊傑 is Distinguished Chair Professor of National Taiwan University.

** Alan T. Wood is emeritus professor of history at the University of Washington Bothell. 
then of $\mathrm{Zhu} \mathrm{Xi}$, might be relevant to the great issues of our present age. We do not claim to have answers. Nevertheless, we believe that China-and Asia in general-deserves to play a greater leadership role in shaping the twentyfirst century. For two centuries, China has been a mirror to the world, reflecting the ideas and institutions of the outside world. Now the world needs it to be a lamp, illuminating a path into the future by offering guidance on global statecraft-jingshi 經世.

\section{Introduction: East Asian Historical Thinking and the Historiographical Tradition}

The Chinese historiographical tradition is long, and it stands tall beside the European tradition. When looking at what qualities most comprehensively manifest the basic characteristics of East Asian culture and thinking, nothing is more long-lasting than the tradition of historical thinking. Since $841 \mathrm{BCE}$, China has preserved documentary historical records, a long, unbroken period of close to three thousand years. Chinese historians wrote about events in order to seek principles behind them, just as one follows a wave in order to find its source. As Zhang Xuecheng 章學誠 (1738-1801) said, “By narrating events in order to reveal principle, talking about $l i$ 理, the events become a model."1 The power of Chinese history lay in seeking to blend principle and events into a seamless whole, one whose value lay in the ability to think deeply about and extract the hidden meaning of specific historical facts. The historian Jao Tsung-I 饒宗頣 (1917-) has said, “Historians esteemed talking about historical events, put great worth on evaluating history based on moral virtue, and definitely did not promote altering virtue based on history."2 Over thousands of years, Chinese historians have upheld innate knowledge, analyzed ancient events and the rise and fall of generations, passed judgment on the virtuous and the wicked, punished the wicked and flattered those already dead, and revealed the dim light of those with hidden virtue. ${ }^{3}$ Historians used a giant pen to alleviate the suffering among the people, to console the souls of those in history who have suffered, and to make, among the readers of history, the dishonest honest and the weak strong, in order to strengthen their resolution and gain control of themselves.

In order to write about the past, present, and future, Chinese historians

1 Zhang Xuecheng 章學誠, “Yuan Dao xia 原道下,” in Yeh Ying 葉瑛 ed, Wenshi Tongyi Jiaozhu 文史通義校注 (Beijing: Zhonghua Shuju, 1994), Vol.2, p.139.

2 Jao Tsung-I 饒宗頣, Zhongguo Shixue shangzhi Zhengtong Lun 中國史學上之正統論 (Hong Kong: Longmen Shuju, 1976), p.57.

3 Qian $\mathrm{Mu}$ 錢穆, Shixue Daoyan 史學導言 [Introduction to History], in Qian Binsi Xiangsheng Quanji 錢賓四先生全集 [Complete Works of Qian Mu] (Taipei: Lianjing chuban gongsi, 1998), Vol.32, p.68. 
established norms, principles, value judgments, and factual judgments in their historical works. ${ }^{4}$ The historical discussions in the writings of Chinese historians from the period of Spring and Autumn became the main current of Chinese historiography. After the narration of important events in the Zuozhuan 左傳, historians used the form "the gentleman said" to judge the mistakes and achievements of historical persons, the causes, and the benefits and losses of historical events. The Grand Historian Sima Qian 司馬遷 (145-90BCE) used "one person's words" to understand "the changes of the present and past," and in the narration of each palace event, he used the term "The Grand Historian remarks" to interject his own interpretation of the historical record and thereby to join the past and present in a single whole. ${ }^{5}$ Ban $\mathrm{Gu}$ 班固 (32-92), in the History of the Former Han (漢書), put at the end of each narrated entry the word “zan 贊," or remark; Fan Ye 范猫 (398-445) used “ping 評," or comments; Sima Guang 司馬光 (1019-1086), in the Northern Song, used "I, Guang, say 臣光曰" in weighing historical events and criticizing the intentions of those in control of events. Twenty centuries later, the great historian Chen Yinke 陳寅恪 (1890-1969), in the Tangdai zhengzhi shishu lungao ${ }^{6}$, used the phrase "Yinke respectfully comments 寅恪案” to mark his own interpretation. All of them were continuing the inherited practices of the historiographical tradition.

The tradition of Chinese historiography also became the model for historians in the region of East Asia. For example, in 1145, the supervisor of writing the national history, Kim Bu-sik 金富軾 (1075-1150), wrote the Samguk Sagi by organizing a narration of historical events of the three kingdoms of Silla, Goguryeo, and Baekje on the Korean peninsula. This was the first work of history on the Korean peninsula. ${ }^{7}$ It was divided into annals, chronological tables, treatises, records, and biographies. To the annals and biographies were often appended remarks to comment on and judge individuals, to embody Kim Bu-sik's intention of establishing the orthodox transmission of the Silla dynasty, and to express his perspective on events, on mythology, and on the Bohai region. ${ }^{8}$ During the Japanese occupation of

4 Chun-chieh Huang 黄俊傑, “Zhongguo Lishi Xiezuo zhong Shilun de zuoyong ji qi Lilun Wenti 中國歷史寫作中史論的作用及其理論問題,” in Rujia Sixiang yu Zhongguo Lishi Siwei 儒家思想與中國歷史思維 (Taipei: National Taiwan University Press, 2014), Chap.2, p.55-86.

5 Xu Fuguan 徐復觀, Liang Han Sixiangshi 兩漢思想史（Taipei: Xuesheng Shuju, 1979), Vol.3, p.321-337.

6 Chen Yinke 陳寅恪, Tangdai Zhengzhi shishu lungao 唐代政治史述論稿 (Shanghai: Shangwu yinshuguan, 1947).

$7 \mathrm{Kim}$ Bu-sik 金富軾 김부식, Samguksagi 三國史記 삼국사기 (Tokyo: Xuesiyuan Dongyang Wenhua Yenjiusuo, 1964).

8 Cf. Miaowei 苗威,“Guanyu Jinfushi Lishiguan de tantao 關於金富軾歷史觀的探討,” in 
Taiwan (1895-1945), the Taiwanese historian Lian Heng 連横 (1878-1936) completed his Comprehensive History of Taiwan, ${ }^{9}$ in which each chapter's beginning and end often used the phrase "Lian Heng says" to cover in detail his concept of ethnic groups and caste. ${ }^{10}$ The phrase lunyue 論曰 in the Samguk Sagi and "Lian Heng yue" 連横曰 in the Comprehensive History of Taiwan both illustrate the Chinese historiographical tradition and its continuity in Korean and Taiwanese historiography.

However, in judgments of historical facts and the daily events of people in the Samguk Sagi and the Comprehensive History of Taiwan, the many value judgments that were applied were mostly hidden and not obvious. In discussions of the value judgments seen in historical documents, historiographical works are obviously very diverse; therefore, the key points of Chinese historical thought most often covered in this essay will focus on the core of historical thinking and on classifying the main categories of historiographical thinking. The four divisions of this essay are: 1) the purpose of studying history; 2) the driving force in historical development; 3) the operating laws of history; and 4) the golden age of history. This article will focus on classifying and analyzing and discussing the meanings of the specific core terms of historical thinking.

\section{The Purpose of Studying History: Comprehensiveness and Statecraft}

In looking at the ultimate purpose of studying history, and in weighing historical events, Chinese historiographers have most often applied two terms: tong 通 (comprehensiveness) and jingshi 經世 (statecraft). Since Sima Qian, or for the past two thousand years of Chinese historiography, the term "tong" has been a core term. The Grand Historian, in his letter to Ren Shaoqing 任 少卿 (124-202), expressed his intention in writing the Shiji, stating, "Being humbly ambitious, I have relied on my untalented language, collected lost old documents from all over, to examine the processes and operations of history, and to investigate the basic principle of success and failure and flourishing and decline. In these altogether 130 chapters I aim to explore the relationship between heaven and humanity, to achieve a comprehensive understanding of

Shehui Kexue Zhanxian 社會科學戰線, (2012: 3), p.101-108.

9 Lian Heng 連横, Taiwan Tongshi 臺灣通史[Comprehensive History of Taiwan] (Shanghai: Huadong Shifan Daxue chubanshe, 2006).

10 Cf. Chen Zhaoying 陳昭瑛, “Lian Heng de Taiwan tongshi yu Qingdai Gongyang Sixiang 連横的《臺灣通史》與清代公羊思想," and “Lian Heng Taiwan tongshi zhong de minzu gainian: jiuxue yu xinyi 連横《臺灣通史》中的「民族」概念:舊學與新義,” in her Taiwan yu chuantong Wenhua 臺灣與傳統文化 (Taiwan: National Taiwan University Press, 2005), pp.104-124 and pp.125-144. 
the changes from ancient times to the present, in order to establish a unified outlook."11

The meaning of the term "tong" was maintained continuously by Chinese historians through successive dynasties. The Tang dynasty scholar Du Yiu 杜 佑 in the Tong dian (801), ${ }^{12}$ the Southern Song Zheng Qiao 鄭樵 (1104-1162) in the Tong zhi (1161), ${ }^{13}$ and Ma Duanlin 馬端臨 (1254-1324/5) in the Wenxian tongkao ${ }^{14}$ all used the concept of "tong" to gain a complete knowledge of the causes of rises and falls in the Chinese historical system. ${ }^{15}$ From the Tang dynasty Shi tong of Liu Zhiji 劉知幾 (661-721) and the Zizhi tongjian of Sima Guang 司馬光 (1019-1086) to the Wenshi tongyi of Zhang Xuecheng 章學誠 (1738-1801) in the eighteenth century, all upheld the concept of tong in their various histories. Therefore, Ban Gu 班固 (32-92), having divided history into periods, is not awarded high stature among traditional Chinese historiographers, even to the extent of Ma Duanlin saying that "comparing Sima Qian to Ban Gu is like comparing a dragon to a pig."16 Zhang Xuecheng regarded the Chunqiu as the beginning of Chinese historiography, its purpose to "cover comprehensively the changes from ancient times to the present, so as to make it one's own philosophy." 17 We can therefore say that "tong" is the first principle of Chinese historiography, and the most important key term in Chinese historical thinking.

The second most important purpose in the study of Chinese historiography was jingshi 經世 “statecraft.” Chinese historiographers industriously gathered historical material and were inspired not only to have a desire to explain the world, but even more to have a desire to change the world, and they believed that the way to change the world was to write works of history that distinguished those who deserved praise and blame, or the worthy and the unworthy, and works that used historical writings and explanations to make the world a better place.

Sima Guang used the annalistic method to compile the Zizhi tongjian,

11 Sima Qian 司馬遷, “Bao Ren An shu 報任安書,” in Ban Gu 班固, Hanshu 漢書 [History of the Former Han] (Taipei: Yiwen Yinshuguan, 1956), juan 62, p.1257.

12 Du Yiu 杜佑, Tong Dian 通典 (Beijing: Zhonghua shuju, 1988).

13 Zheng Qiao 鄭樵, Tong Zhi 通志 (Beijing: Zhonghua shuju, 1987).

14 Ma Duanlin 馬端臨, Wenxian Tongkao 文獻通考 (Beijing: Zhonghua shuju, 1986).

15 Cf. Hok-lam Chan, “'Comprehensiveness' (T'ung) and 'Change' (Pien) in Ma Tuanlin's Historical Thought," in Hok-lam Chan and Wm. Theodore de Bary eds., Yüan Thought: Chinese Thought and Religion Under the Mongols (New York: Columbia University Press, 1982), pp.27-88.

16 Ma Duanlin, "Jingji kao 經籍考,” in Wenxian Tongkao (Beijing: Zhonghua shuju, 1986), Vol.2, p.1622.

17 Zhang Xuecheng 章學誠, “Da Ke Wen Shang 答客問上,” in Ye Ying 葉瑛 ed., Wenshi Tongyi Jiaozhu 文史通義校注, Vol.5, p.470. 
narrating 1,362 years of historical events. Although he never used the term "jingshi," it is easy to see that he emphasized the practical uses of historiography to exhort and enlighten. In explaining his purpose in compiling the Zizhi tongjian, Sima Guang himself said, "I only desired to write about the rise and fall of the states, the joys and sorrows of people, so that observers could select for themselves what they liked or disliked, what worked and what failed, in order to protect themselves; it wasn't like the Chunqiu, to lay down the rules for praise and blame. It was really to bring order out of chaos." 18 In his memorial submitted to emperor Shenzong, he echoed those sentiments: "The Zizhi tongjian principally aimed at chronicling the rise and fall of the states, and was concerned with the joys and sorrows of people, so that they could take the best as a model, and guard against the worst." 19 In Zhang Xuecheng's statement that "the concept of statecraft in historiography was definitely not empty talk," 20 written in the eighteenth century, one can see the basic essence of traditional Chinese historiographical works and the second main reason for the purpose of the study of Chinese history.

\section{The Driving Force in Historical Development: Propensity, Principle, and Ritual}

In Chinese historical thinking concerning the key terms for the motive forces of historical development, there are three concepts: 1) propensity ( $s h i$ 勢); 2) principle ( $l i$ 理); and 3) ritual ( $l i$ 禮). We will consider these three terms in order.

1) Propensity (Shi 勢). When Chinese historiographers pondered the driving force of history, the most important key term was shi, propensity. In the history of ancient Chinese thought, the concept of shi was divided into temporal propensity, shish $i$ 時勢, and situational propensity, xingshi 形勢. The former was concerned with time, and the latter, with space.

Sima Qian in the Shiji often used the term xingshi, as in chapter 17, "The Chronological Table of the Feudal Lords from the Beginning of the Han": "[When] the great states of the feudal lords rose to power, the Son of Heaven was too weak to be able to restore them to order. It was not that his virtue lacked purity, but that the circumstances rendered him helpless." ${ }^{21}$ And in

18 Sima Guang 司馬光, “Weiji (1) 魏紀一,” in Xinjiao Zizhi Tongjian zhu 新校資治通 (Taipei: Shijie shuju, 1976), juan 69, p.2187.

19 Sima Guang 司馬光, “Jinshu biao 進書表," in Xinjiao Zizhi Tongjian zhu, p.9607.

20 Zhang Xuecheng 章學誠, “Zhedong Xueshu 浙東學術,” in Ye Ying 葉瑛 ed., Wenshi Tongyi Jiaozhu 文史通義校注, juan 5, p.524.

21 Sima Qian 司馬遷, “Hanxing yilai Zhuhowang nianbiao 漢興以來諸侯王年表,” in Shiji 史記 [Historian's Record] (Beijing: Zhonghua Shuju, 1959), Bk.3, juan 17, p.801. The English translation follows Burton Watson's translation of the Shiji (vol.1, 
chapter 65, “Biographies of Sunzi 孫子 and Wu Qi 吳起”: “Wu Qi said that the military lords believed that situational power was not as good as virtue, so when applied to Chu, by being cruel and tyrannical, they lost their very bodies." 22 Sima Qian called it one of the driving factors of history, a structural factor apart from any single individual motive, as in economic or geographical factors, similar to what the English historian Peter Burke (1937-) calls the "collective agency" in Western historical thinking. ${ }^{23}$

However, Chinese thinkers and historiographers, in talking about historical "situational power," apart from their focus on objective "collective factors," stressed the more active qualities of people in contemporary historical trends. When Zhu Xi 朱喜 (1130-1200) spoke about the changes from ancient times to the present, although he said "such-and-such was not done by human action," 24 he especially emphasized on the other hand that "only sages are able to find their principle in the midst of constant change." 25 Zhu Xi definitely did not consider individuals to be mere objects ruled by the uncontrollable currents of history. Twenty years after Zhu Xi, the historian Ye Shi 葉適 (1150-1223), in examining those who dominated history, also wrote, "The sages of the past, such as Yao 堯, Shun 舜, Yu 禹, Tang 湯, Wen 文, Wu 武, Gaozu 高祖, and Guangwu 光武 in the Han, and Taizong 太宗 in the Tang, saw themselves as using the power of heaven. Although their merits and virtues were deep, and the results of their rule broad, yet the power of heaven lay with them and not with circumstances." 26 Ye Shi was similar to other Chinese thinkers. All stressed the power of individuals in history to control events.

2) Principle ( $L i$ 理). The second concept that is most often regarded in Chinese historical thought as the most commonly used explanation for the developmental forces of history is principle, $l i$. $L i$ was a core term in Chinese historical thinking. After the rise of neo-Confucianism in the eleventh century, the term profoundly permeated the later phenomena of Chinese historical thought. In the Northern Song, Cheng Yi 程願 (1033-1107), ${ }^{27}$ along

p.488).

22 Sima Qian 司馬遷, “Sunzi Wu Qi Liezhuan 孫子吳起列傳,” in Shiji 史記 [Historian’s Record], Bk.7, juan 65, p.2169.

23 Peter Burke, "Western Historical Thinking in a Global Perspective: 10 Theses," in Jörn Rüsen ed., Western Historical Thinking: An Intercultural Debate (New York, Oxford: Berghahn Books, 2002), pp.15-30.

24 Zhuxi 朱喜, “Gushi Yulun 古史餘論,” in Zhuzi wenji 朱子文集 [Literary Corpus of Master Zhu Xi], Bk.7, juan 72, p.3639.

25 Ibid.

26 Ye Shi 葉適, “Zhishi 治勢,” in Shuixin Xiansheng wenji 水心先生文集 [Literary Corpus of Mister Shuixin] (Taipei: Taiwan Shangwu Yinshuguan, 1965 Sibu congkan chubian suoben), juan 4, p.53.

27 Cheng Yi 程頣、Cheng Hao 程影, Henan Chengshi yishu 河南程氏遺書 [Surviving 
with Zhang Zai 張載 (1027-1077), used the concept of the principle of heaven, tianli 天理, to explain the historical traces of Yao and Shun. ${ }^{28}$

In his explanation of history, Zhu Xi used $l i$ (and sometimes dao) to describe the motive power of historical development. He pointed out that during the period of the Three Dynasties 三代 (san dai), it was popular to attribute the collapse of the Qin and Han to an overflow of emotions; he used li to gain a complete knowledge of his historical perspective valuing the ancient past. Zhu Xi's use of history to explain $l i$, since it was both a natural law and a human standard, was both historical actuality and also a normative imperative. ${ }^{29} \mathrm{Zhu} \mathrm{Xi}$ sometimes saw this motive power of historical development as "the natural power of li." 30

3) Ritual ( $L i$ 禮), ritual or ceremony. Sima Guang was a representative of those Chinese historiographers who took the $l i$ of ritual as the motive power of history. The Zizhi tongjian he compiled narrated the development of 1,362 years of Chinese history, from 403BCE to 959CE. He emphasized that the most important factor in the driving force of history was $l i$. The origin of $l i$ was related to the ceremonies and sacrifices to the gods and ancestors in the society of remote antiquity, and it then spread to become the standard norm for all human relationships. By the Spring and Autumn period (722481BCE), people had already taken $l i$ to be the "basic core of the individual self" 31 or the "basic core of the country." 32 The reference to $l i$ as "that which manages the country, establishes the altars to the gods of earth and grain, puts in order the people, and benefits all descendants" 33 became the common understanding of the term during the Spring and Autumn period. The first historical event that Sima Guang described in the Zizhi tongjian was the

Works of the Henan Chengs], collected in Er Cheng ji 二程集 [Complete Works of the Two Chengs] (Beijing: Zhonghua shuju, 1981), juan 6, pp.3-7.

28 Zhang Zai 張載, “ Jingxue Liku 經學理窟 [Explanations of the Learning of Classics],” in Zhang Zai ji 張載集 [Complete Works of Zhang Zai] (Beijing: Zhonghua shuju, 1978), p.256.

29 See Chun-chieh Huang 黄俊傑, Rujia Sixiang yu Zhongguo Lishi Siwei 儒家思想與中 國歷史思維, chap.6, p.184.

30 Li Jingde 黎靖德 ed., “Yi Gang lu 義剛錄," in Zhuzi yulei 朱子語類 [Classified Conversations of Master Zhu], collected in Zhuzi Quanshu 朱子全書 [Complete works of Master Zhu] (Shanghai: Shanghai Guji chubanshe; Hefei: Anhui Jiaoyu chubanshe, 2002), Vol.18, juan 139, p.4296.

31 Yang Bojun 楊伯峻, Chunqiu Zuozhuan Zhu 春秋左傳注 [Commentaries on the Zuo Commentaries of the Spring and Autumn Annals] (Beijing: Zhonghua shuju, 1981, 1990), Vol.2, p.860.

32 Yang Bojun 楊伯峻, Chunqiu Zuozhuan Zhu 春秋左傳注 [Commentaries on the Zuo Commentaries of the Spring and Autumn Annals], Vol.1, "Xi Gong shiyi nian 僖公 十一年, ” p.338.

33 Yang Bojun, Chunqiu Zuozhuan Zhu, Vol.1, “Yin Gong shiyi nian 隱公十一年,” p.76. 
threefold division of Jin 互 in 403BCE. After narrating events here, Sima Guang uses the phrase "chen Guang yue" 臣光曰 (Your servant Guang says) to open his discussion, emphasizing that "there is no greater duty of a prince than $l i$, with $l i$ nothing greater than analysis, with analysis nothing greater than reputation for integrity - this was the celebrated 'discussion of analysis and reputation mingfen lun 名分論." 34 One can say that $l i$ was the most important term in Sima Guang's historical explanations, whether or not it evolved to become the dominant form of history.

\section{The Operating Laws of History: Dao 道 and Xin 心}

In Chinese historical thinking, the terms $d a o$ and xin are the most important terms for describing the laws of history.

1) Dao 道: Since the time of the Spring and Autumn period, the term dao, whether or not it was used throughout the Chinese world, was the standard of judgment and conduct for the sages and men of virtue to decide whether to take or leave office. Confucius said, "Should the Way fail to prevail, I would put to sea on a raft," 35 and advised a gentleman to "Let yourself be seen when the Way prevails in the empire, but keep out of sight when it does not." 36 Confucius believed that "When the Way prevails in the Empire, the rites and music and punitive expeditions are initiated by the Emperor"; and if the dao does not prevail, then "they are initiated by the feudal lords." 37 Zhang Xuecheng said, "The origin of history is rooted in the Chunqiu; the meaning of the Chunqiu is clearly shown in the way it corrects the composition. The meaning of correcting the composition was undoubtedly to give laws to heaven and man, and to advocate the great Way." 38 Historical writings confirm the efficacy of the term dao in history. The Grand Historian Sima Qian, in writing the biography of Boyi (伯夷列傳), wrote that in conveying the story of Bo Yi and Shu Qi, he encountered feelings of endless sorrow and regret, raising doubts whether or not there was "a dao of Heaven" in history. 39

When we get to Zhu Xi's historical explanations, the term "dao" becomes even more the operant model for history. Zhu Xi talks about history in the

34 Sima Guang 司馬光, Hu Sanxing zhu 胡三省注, Zhang Yu 章鈺 eds., Xinjiao Zizhi Tongjianzhu 新校資治通鑑注, juan 1, pp.2-3.

35 D. C. Lau trans., The Analects (Hong Kong: The Chinese University Press, 1992), Bk. V, Chap.7, p.37.

36 D. C. Lau trans., The Analects, Bk. VIII, Chap.13, p.73.

37 D. C. Lau trans., The Analects, Bk. XVI, Chap.2, p.163.

38 Zhang Xuecheng 章學誠, “Da kewen shang 答客問上,” in Ye Ying 葉瑛 ed., Wenshi Tongyi Jiaozhu 文史通義校注, juan 5, p.470.

39 Sima Qian司馬遷, “Boyi Liezhuan 伯夷列傳,” in Shiji 史記, juan 61, p.852. 
Dachen tongfuba: "Ren refers to a specific person, and dao refers to a specific dao - is that not the difference between the periods of the three dynasties, the Han and the Tang?"40 Zhu Xi believed that the dao was the practical law of history, stating, "From ancient times to the present there is only one system; those who follow it succeed, and those who defy it fail." ${ }^{11}$ He furthermore said that if rulers "significantly lack the dao," then history would enter into "a kind of primal chaos, human society would collapse, and rise again another day." 42 Zhu Xi believed that the explanations of Chinese history demonstrated a kind of "worship of ancient historical outlook," and that the dao of Yao, Shun, the three kings, Zhougong, and Confucius was never implemented in heaven or earth for even one day." 43

2) [Xin 心 heart] The practical principle in Chinese historical thinking lies in the purity of the ruler's "heart." Chinese historiographers were saturated in traditional Confucian thought, believing deeply that to see whether or not history followed the right path, one must look closely at the "heart" of the rulers. Mencius therefore said that one must take "rectifying the evils in the prince's heart" as the key task. ${ }^{44}$ At the end of the Ming and the beginning of the Qing, Wang Fuzhi (1619-1692) created a broad overview of historical successes and failures. In pointing out the practical principles of history, he said that "the qualifications to rule are solely in the heart. If one uses the heart to govern, then whoever rules cannot avoid benefiting the people...Therefore the qualifications of a ruler lie only in the heart, and form a mirror to history." 45 In Chinese historical thinking, history becomes a matter of making concrete the good and evil of the human heart (particularly the heart of the ruler) and the process of its development.

\section{The Golden Age of History: The Three Dynasties}

In Chinese traditional historical thought has always existed a yearning to

40 Zhu Xi 朱喜, “Da Chen Tongfu Ba 答陳同甫八 [Eighth Reply to Chen Tongfu],” in Zhuzi Wenji 朱子文集 [Literary Corpus of Master Zhu Xi], Vol.4, juan 36, p.1464.

41 Zhu Xi 朱喜, “Da Chen Tongfu Jiu 答陳同甫九 [Ninth Reply to Chen Tongfu]," in Zhuzi Wenji 朱子文集 [Literary Corpus of Master Zhu Xi], Vol.4, juan 36, p.1466.

42 Li Jingde 黎靖德 ed., “Yang lu 揚錄," in Zhuzi yulei 朱子語類 [Classified Conversations of Master Zhu], collected in Zhuzi Quanshu 朱子全書 [Complete works of Master Zhu] (Shanghai: Shanghai Guji chubanshe; Hefei: Anhui Jiaoyu chubanshe, 2002), Vol.14, juan 1, p.121.

43 Zhu Xi 朱喜, “Da Chen Tongfu Liu 答陳同甫六 [Sixth Reply to Chen Tongfu]," in Zhuzi Wenji 朱子文集 [Literary Corpus of Master Zhu Xi], Vol.4, juan 36, p.1458.

44 D. C. Lau trans., Mencius (Hong Kong: The Chinese University Press, 1984), Vol.1, Bk. IV, Part A, chap.20, p.152.

45 Wang Fuzhi 王夫之, Du Tongjian lun 讀通鑑論 [Remarks Gathered from a Reading of the Comprehensive Mirror to Aid in Government] (Changsha: Yulu shushe, 1989), Vol.10, pp.1181-1182. 
return to the golden age of antiquity. This is expressed by the term "three dynasties", which constantly appears in the narrative of traditional Chinese histories. Confucius made the Xia 夏, Shang 商, and Zhou 周 (the "three dynasties") into the golden age of China, "He transmitted the ancient traditions of Yao and Shun, and he modeled after and made brilliant the systems of King Wen and Wu." 46 Confucius often glorified the three dynasties, comparing them with the period of Spring and Autumn. Mencius, in looking back on history, regarded it almost as a law of history, saying, "The three dynasties won the Empire through benevolence and lost it through cruelty. This is true of the rise and fall, the survival and collapse, of states as well." ${ }^{\prime \prime}$ Confucius and Mencius, in discussing the role of the three dynasties in Chinese historical thinking, often saw them as related to the rise and fall of the dao. In regarding the three dynasties as the golden age of antiquity in Chinese historical thought, the historical discussions of Confucians and historiographers often treat it as a contrast or counterpoint to the "real world," and thus have a "counter-factual" characteristic. ${ }^{48}$

\section{Conclusion on Chinese Historiographical Terms}

This essay has thus far discussed and summarized key terms that frequently appear in Chinese historical narrative and Chinese historical explanations. According to this essay, Chinese historiographers, in expressing the purpose of studying history, most frequently employed the terms "comprehensiveness" (tong 通) and "statecraft" (jingshi 經世). Ever since Sima Qian, the phrase "to comprehend the changes from ancient times to the present" (tong gujin zhi bian 通古今之變) has been the unresolved goal of Chinese historians. Therefore, the Tongzhi, Tongdian, and Wenxian tongkao, in systematically carrying out the above-mentioned principle in writing history, and the Zizhi tongjian, in using the annalistic method of narrating history, provide a mirror to the rulers. The fact that Chinese historiography especially emphasized "tong gujin zhi bian" demonstrates that the main goal of writing history was statecraft. Chinese historiographers used not only the heart and mind to explain the world; they also used power to change the world.

Second, with regard to the motive of historical development, Chinese historiographers also focused on the three terms shi 勢, $l i$ 理, and $l i$ 禮. However, although Chinese historiographers admittedly emphasized the

46 Wing-tsit Chan, trans., The Doctrine of the Mean, collected in A source Book in Chinese Philosophy (Princeton New Jersey: Princeton University Press, 1973), p.111.

47 D. C. Lau trans., Mencius, Vol.1, Bk. IV, Part A, chap.3, p.141.

48 See Chun-chieh Huang 黄俊傑, Rujia Sixiang yu Zhongguo Lishi Siwei 儒家思想與中 國歷史思維, pp.115-120, for more reflections on this subject. 
dispositions of shi and $l i$, and the power of structural elements, they did not believe that these inevitably operated according to some mechanistic law; rather, they emphasized the active agency of individuals, emphasizing that people had free will in order to lead history in a positive direction.

Third, in Chinese historical thought relating to the laws of historical operation, the terms most often used were dao 道 and xin 心. Chinese historiographers deeply absorbed Confucian values, believing that in history, the presence or absence of dao was indicative of order or chaos, and the key especially was in whether historical figures and rulers preserved xin. All this shows that Chinese historical thinking was permeated with a strong spirit of optimism and a foundation of humanism.

Fourth and last, the three dynasties period in Chinese historical thinking became the golden age that all Chinese historiographers yearned for. Chinese historiographers often idealized the three dynasties in order to criticize and instruct real life politics, with the intention of converting the "is" of the real world to the "ought to be" of the virtuous world. The humanistic spirit of the tradition of Chinese historiography, and the faith in transforming the world, is fully manifested in this tradition.

From our discussion here of the main terms in Chinese historical thinking, we can see that the aim of Chinese historiographers in writing history, and in writing about the driving force of history, the laws of historical change, and their yearning for the golden age, all manifested how deeply they stressed the role of human action in history. They believed not that people were passive tools of objective historical forces but that the upright human will was capable of overturning heaven and earth and of being a solid rock in a constant stream of historical change. Therefore, in the eyes of Chinese historiographers, the purpose of studying history was not just to accumulate historical facts. It was to receive heartfelt inspiration by reading about the ancient worthies and past sages and to devote oneself to making the world a better place, ordering the state, and saving the world.

\section{Further Thoughts on the Relevance of the Chinese Historiographical Tradition for the Future of the World: Three Periods of Grand Synthesis}

This part focuses on how the terms outlined in the proceeding sections of this paper might be applied to the challenges facing the current generation of leaders, not only the challenges in China but those in the world at large. The authors of this essay believe that these terms convey profound wisdom, and that they therefore offer insight into the problems we face today as a human community. As discussed above, in the past, the $l i$ of principle and the li of ritual were rooted in a belief that the moral laws of human behavior 
were modeled on the natural laws of the cosmos itself. When those laws were ignored or violated, then heaven (tian) intervened to punish the evil and reward the good. The historian's role was to reveal those laws in specific historical events so that the future could apply the relevant lessons to practical statecraft (jingshi). The underlying assumption was that nature was systemic and that its fundamental essence consisted of relationships. Everything was assumed to be connected to everything else, such that the internal motivation of the heart (xin) was the key to evaluating external behavior and judgment. One could not gain a full understanding of any given phenomenon by looking only at one aspect of it. One had to look at the whole, at the larger context. One had to be, in short, comprehensive (tong). To be otherwise was to grasp only a part of the truth.

All these perspectives are immediately relevant to the great questions of our age today. This section will outline one possible avenue of "making the world a better place, ordering the state, and saving the world" by looking at two periods in Chinese history in the past that produced a grand synthesis of ideas and then suggesting that these two periods offer an insight into a potential third period of synthesis in the future. The first period was the lifetime of Confucius himself and his followers in the Eastern Zhou. The second period was the neo-Confucian revival of the Northern and Southern Song dynasty (960-1279). We are now on the threshold of a third major period of synthesis, this time calling for China to take a global perspective, a perspective that embraces the full expanse of all under heaven, tianxia. All three periods share one important quality - an existential crisis threatening the very foundation of orderly life and requiring a re-design of the basic institutions of governance.

\section{First synthesis}

The first period of synthesizing renewal-during the time of Confucius and then of Mencius - gave rise to the basic concepts and terms discussed in the previous sections. The Eastern Zhou was fraught with constant conflict. China was divided into hundreds of states, forming and dissolving alliances, competing for power, and falling in and out of war. The bonds of trust necessary for cooperation had broken down. In this world of disorder, the central preoccupation of doers and thinkers alike was governance: how to re-build a strong and just society in an imperfect world. The key insight of Confucius and his followers was that all institutions of good governance must be rooted in the deepest yearnings of the human heart for justice and meaningful human relationships. Force alone is insufficient for keeping power over a long period. To be legitimate, as well as sustainable, government had to be built on a foundation of a shared code of moral behavior, which Confucius identified 
as "humanity" ("benevolence," "reciprocity," ren 仁). That was a remarkable assertion, given that during his lifetime politics seemed to be far more focused on force than on moral virtue.

\section{Second synthesis}

The second period of renewal occurred in the Song dynasty. Then, as during the time of Confucius, China was facing an existential threat to the unity of Chinese civilization. In the 740 years from the end of the Han dynasty to the beginning of the Northern Song, China had been divided for 574 years (including the period in the Tang following the An Lushan Rebellion); in other words, for 77 percent of the time, China had been vulnerable to civil war or to attack and occupation by Central Asian peoples. Now, in the tenth century, China had been reunified under a new dynasty. The question was how that unity could be sustained. The first step was to prevent the rise of local military commanders, the jiedushi 節度使, who had undermined the unity of China in the Tang. Song thinkers tackled the problem of how to centralize power, shi 勢, by advocating a doctrine of zunwang rangyi 尊王攘夷, “revere the ruler and expel the barbarians." The initial vehicle for these ideas were commentaries on the Chunqiu, of which the most prominent in the Northern Song was the Chunqiu zunwang fawei 春秋尊王發微 of Sun $\mathrm{Fu}$ 孫復 (992-1057). (In a fascinating example of the relevance of these early Song thinkers to the larger region of East Asia, the term zunwang rangyi was borrowed by late Tokugawa reformers in Japan in the nineteenth century to become the rallying cry of the Meiji Restoration-sonno joi.)

The underlying intention of the Song political philosophers, however, was not so much to concentrate power in the person of the individual ruler as it was to centralize the institutions of government into the hands of a highly educated, morally upright elite imbued with the ethical values of public service and the wisdom of historical experience. Song thinkers believed deeply that the strength of China depended on nothing less than the moral renewal of Chinese society. That moral renewal, in turn, required them to breathe new life into the Confucian worldview, which in the centuries after the fall of the Han dynasty had lost its pride of place among the Chinese literati. Daoism, with its cosmological metaphysics, and Buddhism, with its complex philosophical speculation on the nature of being as well as suffering, had come to dominate the intellectual terrain of China. In order to make Confucianism relevant to their own age, the Song thinkers had to take into account the perspectives of the Daoist and Buddhist worldviews that had claimed the attention of Chinese intellectuals for so many centuries. They did so not by denying the validity of those two traditions but by affirming them, incorporating their essential truths into a new Confucian whole, a synthesis, 
that was greater than the sum of its aggregate parts.

There were many thinkers in the Northern Song who laid the philosophical foundation for this neo-Confucian renaissance. Common to all was a desire to link the terms discussed in the first part of this essay into a single unifying body of theory, and to do so by drawing on the Daoist and Buddhist philosophical heritage as well as the Confucian classics. The oldest of the group that was to have a transformative impact on this renaissance was Shao Yong 邵雍 (1011-1077), who was fascinated with the Yijing 易經 (Book of Change) and its exploration of the relationship between numbers and nature (much as Western thinkers were intrigued by the way in which mathematics - a purely human invention - reveals fundamental patterns in nature). Others included the brothers Cheng Hao 程影 (1032-1085) and Cheng Yi 程 頣 (1033-1107), who focused on principle, $l i$, and its connection with heartand-mind, xin, and dao. Zhou Dunyi 周敦頣 (1017-1073) made a central contribution by borrowing from Daoist cosmology the concept of the Supreme Polarity, taiji 太極, a dynamic and complementary unity of opposites. ${ }^{49}$ Zhang Zai 張載(1020-1077) also focused on taiji, which he believed to be the source of all the constituent matter in the universe-qi. Represented visually by the taijitu 太極圖 (the yin-yang symbol), this concept became one of the central ideas of the neo-Confucian movement.

These various threads created by Northern Song thinkers were woven into a single tapestry unifying thought and action by Zhu Xi's grand synthesis in the Southern Song. Using the agency of taiji, Zhu Xi joined into a single whole the two concepts of principle, $l i$ 理, and material force, $q i$ 氣, in such a way that the central Confucian virtue of reciprocity became a manifestation of the basic nature of the cosmos itself. The result was a stupendous intellectual achievement - a synthesis on a scale commensurate with that of Thomas Aquinas (1225-1274) in thirteenth-century Europe. For the next thousand years, Confucianism once again formed the basis of the cultural unity of China and the standard by which all institutions of governance were measured not only in China but in the East Asian region as a whole.

In the context of world history, the cultural and political sustainability of the ideas and institutions of Confucian China is remarkable and unique. Lasting for two thousand years, and comprehending one-quarter of the earth's total population at a time when communication over long distances was so slow as to be virtually non-existent (at least by today's standards), its genius

49 We follow Joseph A. Adler's translation here. See his Reconstructing the Confucian Dao: Zhu Xi's Appropriation of Zhou Dunyi (Albany: State University of New York Press, 2014), especially ch.4, pp.111-136. The term has been traditionally translated into English as the "Supreme Ultimate." 
lay in its ability to balance opposites over time and to see the world in its full complexity as a system of dynamic and inherently moral relationships. It was, simultaneously, both centralized and de-centralized, unified and divided, topdown and bottom-up, integrated and autonomous, idealistic and realistic, favoring continuity but enabling change, rooted in the past but preparing for the future, encouraging cooperation but permitting competition. Above all, it brought life and thought, theory and practice, into a synoptic vision of moral truth. Everything was related to everything else, and moral responsibility grew naturally out of seeing the world as a vast network of relationships.

\section{Third synthesis}

The third period of grand synthesis in Chinese history is the present, or more precisely, the immediate future. At the beginning of the twenty-first century, three major developments have converged, fundamentally changing the landscape of Chinese - and human - civilization and presenting an existential challenge on the same order of magnitude that occurred in the time of Confucius and Zhu Xi. First, the massive military power that Europe had acquired in the Scientific and Industrial Revolutions, and which had been directed at conquering overseas colonial empires in the nineteenth century, was in the first half of the twentieth century turned inward on Europe itself. In two world wars only twenty years apart, Europe essentially self-destructed. By the middle of the twentieth century, after centuries of global ascendancy, it was no longer a player on the world scene. The second major development, in the second half of the twentieth century, was that the industrial revolution itself crossed the Pacific Ocean to Asia. China is now poised to reclaim its prior status as the main engine of the global economy. India is close behind.

The third major development was globalization itself. Until the relatively recent past, the technology of transportation, communication, and information was such that most nations of the world could maintain at least the illusion of autonomy and independence. Those days, for the first time in human history, are over. The global scale of the challenges we now face, among the most urgent of which are climate change, disease, weapons proliferation, migration, and crime, transcend the artificial borders of our nation-states. Now the human species is facing an existential challenge to the future welfare of the entire population of the earth, requiring a quantum leap in the level of cooperation on the same order of magnitude as the great institutional transitions of the past (from hunter-gatherer to village to city to state), this time to a truly global level of cooperation. Yet the ideas and institutions of governance we have inherited from the past are no longer adequate to address those challenges successfully. As in the late Zhou and the Northern Song, there is no conceptual framework that can facilitate cooperation among all the competing 
interests of the existing states. In the absence of a fundamental level of trust that comes from a shared cultural background, or a shared system of moral values, or a fair and equitable institution of administering justice, power alone prevails.

Given our current predicament, and the similarity of the challenges we confront today to those of the two periods of Confucian synthesis noted above, are there any insights that could be gleaned from the past to apply to the present? Drawing from what Chinese historians and thinkers did in the past - as illustrated by all the terms covered in the first part of this essaythere appear to be at least three necessary conditions for a sustainable system of global governance:

1. A unifying goal or system of thought based on evidence that has universal credibility.

2. A system that is fundamentally moral in order to inspire trust and cooperation.

3. A system capable of reconciling opposites and competing interestswhich are inevitable in both nature and human society-in the context of a larger and complementary whole.

No one system of thought now in existence is able to meet all three of these criteria to provide a coherent vision for global governance capable of addressing the most urgent challenges of the twenty-first century. The dim outlines of such a truly global worldview, however, may already be lying on the table in front of us. Modern science certainly possesses the first criterion of universal credibility in the modern world in spite of its lack of the second and third criteria. Its success in producing the scientific and industrial revolutions has bestowed a mantle of authority enjoyed by no other system of thought in the modern world. The Confucian worldview, on the other hand, certainly possesses the second and third criteria, and it has demonstrated its sustainability over the past two thousand years. If so, then the next logical question to ask is whether there is any evidence that these two worldviews, one from the West and the other from the East, might be combined in a new synthesis on the same order of magnitude accomplished by Confucius himself and then by Zhu Xi.

There might well be. For decades, the basic mechanistic paradigm of Western science (based on nature, of course) has itself already been moving in a direction compatible with the Chinese paradigm of yin-yang complementarity of opposites (also based on nature) employed by Zhu Xi to synthesize Confucianism, Daoism, and Buddhism. Many sciences are adopting a more holistic, systems, ecological, and interdisciplinary understanding focused on complex relationships and interconnections. The new trend began a century 
ago with quantum physics, when it was discovered that in the subatomic world, the classical laws of physics do not apply. Within the atom, matter and energy seem to be entirely complementary, perpetually changing back and forth in such a mysterious way that they are best understood as both matter and energy simultaneously, depending entirely on how they are measured. Certainty was balanced by uncertainty, objectivity by subjectivity, determinant cause by probability, independent variable by interdependent variable, linear by non-linear. The core constituent substance of the cosmos, moreover, was not a static material reality but a dynamic shifting network of relationships.

Quantum physics was thus the first shot across the bow of the mechanistic perspective that until then had characterized the modern scientific worldview. Gradually scientists in other fields, in ecology, biology, engineering, mathematics, the cognitive sciences, and medicine, began to notice that nature was composed of complex interactive systems whose properties emerged only at the level of the whole, systems that could not be fully understood by analyzing the parts alone. The systems perspective has since continued to spread to other disciplines. ${ }^{50}$ In other words, a major conceptual shift is now beginning to take place in Western academic institutions, which, for more than a century, divided human knowledge into isolated silos known as disciplines and focused on them largely in isolation from the insights of other disciplines. They did this for perfectly justifiable reasons stemming from the need to specialize in order to master the vast complexity of that knowledge base. In doing so, however, they lost sight of the interactions of those parts in a larger whole and are now moving to address that gap in the form of interdisciplinary programs and teams. In essence, science is now discovering a holistic perspective that has been at the core of the Chinese worldview for thousands of years, one that was most clearly articulated in the Daoist and Confucian concept of taiji. Like the spans of a bridge from two sides of a river joining in the middle, the two continents of thought, one from the East and the other from the West, are now reaching out to each other.

If science is moving toward a more systemic, organic, and holistic perspective, what about the moral component, the second and third requirements mentioned above for a sustainable system of governance? Given the human potential for hatred, violence, cruelty, and self-destruction, how can one possibly expect people to acknowledge the existence of moral truth? Does not every society, including China, provide plenty of evidence of human perversity? Certainly. But the real issue is not whether humans can

50 For a more complete understanding of the history of systems thinking, see Fritjof Capra and Pier Luigi Luisi, The Systems View of Life: A Unifying Vision (New York: Cambridge University Press, 2014). 
become perfect. Rather, it is whether they can become better, able to curb their selfish desires enough to form cooperative civilized institutions. The institution of law goes a long way in making that possible. But in the end, law can only prevent people from doing what is wrong. It cannot inspire people to do what is right. Only morality can do that. Morality, in turn, comes from realizing that we are related to each other so intimately that harming someone else is harming oneself, and that benefiting someone else is benefitting oneself. Morality, in other words, is based on relationships, starting with the most basic relationship in nature- the love between a mother and her baby. Moral principle is not something imposed from without but something that grows naturally from within, something that stems from the essential unity of all things and from the need for the interrelated parts of a larger whole to cooperate with each other. That was the core insight of Confucius, of $\mathrm{Zhu} \mathrm{Xi}$, of the Buddha, and of all major religious figures throughout the human experience. It was behind the northern Song thinker Zhang Zai when he wrote in the "Western Inscription" the following passage basing humanistic ethics on the unity of all things: "Heaven is my father and Earth is my mother, and even such a small creature as I finds an intimate place in their midst. Therefore that which extends throughout the universe I regard as my body and that which directs the universe I regard as my nature. All people are my brothers and sisters, and all things are my companions." 51

Science, starting with quantum physics, is now coming around to that unified perspective as well by focusing on complementary relationships as the basic principle of all reality, such that subject and object, observer and observed, matter and energy, are in a mutual and interactive dance- the taiji. Perhaps that convergence may form the basis for a new synthesis of East and West that can apply to our own age the $l i$ of principle, and carry forward into the next century Sima Qian's grand intention "to explore the relation between heaven and humanity." Just as Sima Qian's Shiji was revolutionary in his own time by expanding historical experience to cover all of the known world, not just China, we are proposing that the principles of Chinese historiography covered in the first sections of this essay might usefully be expanded to comprehend the full expanse of the human prospect and provide the language for a global humanistic ethics.

Such a synthesis of ideas and institutions now requires the participation of the entire human community. Asia, where 60 percent of the world's

51 Wm Theodore de Bary and Irene Bloom, eds., Sources of Chinese Tradition from Earliest Times to 1600, $2^{\text {nd }}$ edition (New York: Columbia University Press, 1999), p.683。“乾稱父, 坤稱母; 予茲藐焉, 乃混然中處。故天地之塞, 吾其體; 天地之帥, 吾 其性。 民,吾同胞;物, 吾與也.” 
population lives, must play a leadership role commensurate with its economic and political stature. A global system of governance that does not incorporate Asian perspectives and Asian leadership will be neither workable nor sustainable. So what is needed now is a dialogue among Chinese philosophy and history, global ethical and religious traditions, and science to develop a common language of global humanism that will lay the foundation for new institutions of trust and cooperation that transcend the nation-state and that can bring lasting peace to the world, or in the words of Confucius himselfping tianxia 平天下. 